\title{
Pengembangan Media Pembelajaran Interaktif Berbasis Adobe Flash Professional CS6 Pada Program Studi Sastra Agama Dan Pendidikan Bahasa Bali STAHN Mpu Kuturan Singaraja
}

\author{
I Nengah Adi Widana ${ }^{1}$, I Nengah Juliawan², Made Suardika Jaya ${ }^{3}$, \\ I Wayan Juliana ${ }^{4}$ \\ ${ }^{1234}$ STAHN Mpu Kuturan Singaraja \\ 1 adiwidana2@gmail.com, ${ }^{2}$ camebinkjulian@gmail.com, \\ ${ }^{3}$ suardikajayamade@gmail.com, ${ }^{4}$ julianawayan69@ gmail.com
}

\begin{abstract}
Education in Indonesia in March 2020 experienced significant turmoil, this was due to the pandemic caused by Covid-19. Learning that was initially carried out face-toface, was then carried out online by applying or using more effective learning media. One of them is by using Adobe Flash Professional CS6. The researcher uses a Research and Development $(R \& D)$ model with a 4-D (four D) model through the development stages including Define, Design, Develop, and Disseminate. The results showed that the media feasibility level which was validated by equipment experts showed a feasibility level with a percentage of $88.75 \%$. Meanwhile, the feasibility level of the material expert shows the feasibility level with a percentage of $93.75 \%$. The responses given by educators and students are carried out by conducting product trials, then educators and students are asked to fill out a questionnaire using the google form application. As for the results in terms of educators responding with a percentage of $83.13 \%$ satisfying and from students getting a response with a percentage of $80.61 \%$ satisfactory.
\end{abstract}

Keywords: Learning Media Development; Adobe Flash Professional CS6 Education

\begin{abstract}
Abstrak
Pendidikan di Indonesia pada bulan Maret 2020 mengalami gejolak yang signifikan, hal ini disebabkan karena terjadinya pandemi yang disebabkan oleh Covid-19. Pembelajaran yang awalnya dilaksanakan secara tatap muka, kemudian dilaksanakan secara online dengan menerapkan atau menggunakan media pembelajaran yang lebih efektif. Salah satunya adalah dengan pemanfaatan Adobe Flash Profesional CS6. Peneliti menggunakan model Penelitian dan pengembangan atau Research and Development (R\&D) dengan model 4-D (four D) melalui tahapan pengembangan meliputi Define, Design, Develop, dan Disseminate. Hasil penelitian menunjukkan tingkat kelayakan media yang divalidasi oleh ahli perangkat menunjukkan tingkat kelayakan dengan persentase sebesar 88,75\%. Sedangkan untuk tingkat kelayakan dari ahli materi menunjukkan tingkat kelayakan dengan persentase sebesar 93,75\%. Respon yang diberikan oleh pendidik dan peserta didik dilakukan dengan cara mengadakan uji coba produk, selanjutnya pendidik dan peserta didik diminta untuk mengisi kuesioner dengan menggunakan aplikasi google formulir. Adapun hasilnya dari segi pendidik memberikan respon dengan persentase $83,13 \%$ memuaskan dan dari peserta didik memperoleh respon dengan persentase $80,61 \%$ memuaskan.
\end{abstract}

Kata Kunci: Pengembangan Media Pembelajaran; Adobe Flash Professional CS6 Pendidikan 


\section{Pendahuluan}

Pendidikan yang bermutu diperlukan dalam proses pematangan kualitas peserta didik yang dikembangkan dengan cara membebaskan peserta didik dari ketidaktahuan, ketidakmampuan, ketidakberdayaan, ketidakbenaran, ketidakjujuran, dan dari buruknya moral dan etika. Sistem pembelajaran saat ini mengalami perubahan yang signifikan, karena ketidaksiapan SDA maupun SDM Lembaga menyikapi perubahan yang terjadi. Perubahan ini disebabkan karena munculnya pandemi Covid-19 yang melanda dunia sudah lebih dari 1 tahun terakhir ini berdampak terhadap perubahan aktifitas belajarmengajar. Tak terkecuali di Indonesia, sejak memasuki bulan maret 2020, aktifitas pembelajaran daring (online learning) menjadi sebuah pilihan kementerian pendidikan dan kebudayaan untuk mencegah penyebaran virus Covid-19 semakin meluas.

Proses belajar dalam jaringan tentu membutuhkan sebuah efisiensi dan inovasi, dan sebuah teknologi perlu dikuasi oleh tenaga pendidik. Teknologi pembelajaran mempunyai peran untuk memfasilitasi pembelajaran dan meningkatkan kinerja dengan cara menciptakan, menggunakan, atau memanfaatkan dan mengelola proses dan sumbersumber teknologi yang tepat. Salah satunya adalah software (perangkat lunak) yang sebagaian besar dalam genggaman para siswa. Perangkat lunak sangat dekat dengan kehidupan peserta didik saat ini, selain sebagai fungsi komunikasi, perangkat lunak juga sangat berpotensi dikembangkan menjadi media pembelajaran interaktif yang bermanfaat bagi peserta didik. Selain sebagai fungsi komunikasi, perangkat lunak juga sangat berpotensi dikembangkan menjadi media pembelajaran interaktif yang bermanfaat bagi peserta didik. Penggunaan media pembelajaran berbasis pada software merupakan salah satu penerapan gaya belajar abad ke 21. Penggunaan media pembelajaran sejenis ini berpotensi untuk membantu meningkatkan performa akademik peserta didik berupa hasil belajar pada ranah kognitif dan motivasi belajar peserta didik.

Salah satu media pembelajaran interaktif berbasis software adalah Adobe Flash professional CS6 adalah salah satu produk/software dari Adobe yang digunakan untuk proses membuat dan mengolah animasi atau gambar yang menggunakan vektor untuk skala ukuran kecil. Software ini penggunaanya ditujukan untuk membuat animasi atau aplikasi yang bersifat online, namun seiring dengan perkembanganya Adobe Flash digunakan untuk membuat animasi atau aplikasi yang bersifat offline. Secara fungsional dalam proses pembelajaran saat ini yang berada dalam fase daring, penggunaan software ini memberikan kontribusi dalam membuat atau mengembangkan media pembelajaran atau bahan ajar serta ujian dan kuis yang ditujukan untuk para peserta didik.

Mengingat pentingnya sebuah pengembangan untuk kemajuan sebuah program studi, terlebih dalam kontekstual isian mata kuliah yang berkiblat pada pendidikan Bahasa bali, dimana muatan mata kuliahnya lebih banyak terdapat materi-materi aksara dan sastra daerah, yang saat ini masih minim dituangkan dalam bentuk digitalisasi, maka peneliti melaksanakan penelitian ini yang berangkat berdasarkan ketidaksiapan SDA dan SDM dalam menyikapi sistem pembelajaran daring, berdasarkan hal tersebut penting bagi peneliti untuk melakukan penelitian terkait pengembangan media pembelajaran interaktif berbasis adobe flash professional CS6 pada Program Studi Sastra Agama dan Pendidikan Bahasa Bali STAHN Mpu Kuturan Singaraja, guna memberikan sebuah efisiensi dalam proses pembelajaran serta inovatif dalam mengembangkan program studi menjadi lebih unggul dan terdepan dalam menghasilkan lulusan yang siap dan sigap mengikuti perkembangan sistem pendidikan. 


\section{Metode}

Penelitian pengembangan media pembelajaran interaktif berbasis adobe flash professional CS6 merupakan penelitian pengembangan atau Research and Development (R\&D) yang merupakan suatu proses yang digunakan untuk mengembangkan dan/atau memvalidasi produk pendidikan. Penelitian pengembangan ini mengikuti suatu langkahlangkah secara siklus, yang terdiri dari kajian tentang temuan penelitian produk yang akan dikembangkan, pengembangan produk berdasarkan temuan-temuan tersebut, melakukan uji coba lapangan sesuai dengan latar dimana produk tersebut akan dipakai, dan melakukan revisi terhadap hasil uji lapangan. Rancangan penelitian dan pengembangan media pembelajaran yang digunakan mengacu pada rancangan penelitian dan pengembangan modifikasi dari model pengembangan 4-D (Four D). Pengembangan model 4-D terdiri dari 4 tahap utama yaitu: Define (Pendefinisian), Design (Perancangan), Develop (Pengembangan) dan Disseminate (Penyebaran). Metode dan model ini dipilih karena bertujuan untuk menghasilkan produk berupa media pembelajaran interaktif berbasis Adobe Flash Professional CS6.

Data akan dianalisis secara deskriptif kualitatif. Data yang dianalisis meliputi kelayakan media pembelajaran, dan respon peserta didik. Penilaian kualitatif kelayakan media pembelajaran dan respon dilakukan melalui penilaian checklist. Hasil penilaian dari dosen ahli berupa kualitas produk dikodekan dengan skala kualitatif kemudian dilakukan pengubahan nilai kualitatif menjadi nilai kuantitatif dengan ketentuan sebagai berikut:

Tabel 1. Pengubahan Nilai Kualitatif menjadi Nilai Kuantitatif

\begin{tabular}{|c|c|}
\hline Nilai & Angka \\
\hline Sangat baik & 4 \\
\hline Baik & 3 \\
\hline Kurang & 2 \\
\hline Sangat Kurang & 1 \\
\hline
\end{tabular}

Sumber: Djemari Mardapi (2008: 122)

Teknik analisis data untuk kelayakan media pembelajaran didik berbasis Adobe Flash Professional CS6 dan respon peserta melalui lembar validasi dilakukan dengan langkah-langkah sebagai berikut:

1. Tabulasi semua data yang diperoleh untuk setiap komponen dari butir penilaian yang tersedia dalam instrumen penilaian.

2. Menghitung skor total rata-rata dari setiap komponen dengan menggunakan rumus:

$$
\overline{\mathrm{X}}=\frac{\sum \mathrm{X}}{\mathrm{n}}
$$

(Ngalim Purwanto, 2012: 101)

$$
\begin{array}{ll}
\text { Keterangan: } \\
\overline{\mathrm{X}} \quad \text { = skor rata-rata tiap aspek } \\
\sum \mathrm{X} & =\text { jumlah skor tiap aspek } \\
\mathrm{n} & =\text { jumlah nilai }
\end{array}
$$

3. Mengubah skor rata-rata menjadi nilai dengan kriteria

Untuk mengetahui kualitas media pembelajaran interaktif berbasis Adobe Flash Professional CS6 hasil pengembangan dan respon peserta didik, maka data yang mula-mula berupa skor diubah menjadi data kualitatif (data interval) dengan skala likert. Skala likert, skor tertinggi setiap butir adalah 4 dan yang terendah adalah 1 . 
Adapun acuan pengubahan skor menjadi skala empat dapat dilihat pada tabel berikut ini:

Tabel 2. Acuan Pengubahan Skor Menjadi Skala Empat

\begin{tabular}{cccc}
\hline No & Rentang Skor & Nilai & Kategori \\
\hline 1 & $\mathrm{X} \geq \overline{\mathrm{X}}+1 . \mathrm{SB}_{\mathrm{x}}$ & A & Sangat Baik \\
\hline 2 & $\overline{\mathrm{X}}+1 . \mathrm{SB}_{\mathrm{x}}>\mathrm{X} \geq \overline{\mathrm{X}}$ & $\mathrm{B}$ & Baik \\
\hline 3 & $\overline{\mathrm{X}}>\mathrm{X} \geq \overline{\mathrm{X}}-1 . \mathrm{SB}_{\mathrm{x}}$ & $\mathrm{C}$ & Cukup Baik \\
\hline 4 & $\mathrm{X}<\overline{\mathrm{X}}-1 . \mathrm{SB}_{\mathrm{x}}$ & $\mathrm{D}$ & Kurang Baik \\
\hline
\end{tabular}

$$
\begin{array}{ll}
\text { Keterangan: } \\
\overline{\mathrm{X}} \quad=\text { rerata skor secara keseluruhan } \\
& =\frac{1}{2}(\text { skor maksimal }+ \text { skor minimal }) \\
\mathrm{SB}_{\mathrm{x}} & =\text { simpangan baku skor keseluruhan } \\
& =\frac{1}{6}(\text { skor maksimal }- \text { skor minimal }) \\
\mathrm{X} & =\text { skor yang didapat }
\end{array}
$$

Berdasarkan rumus pada tabel 2, maka dapat dibuat konversi penilaian skala empat.

Tabel 3 Hasil Konversi Skor menjadi Skala Empat

\begin{tabular}{ccccc}
\hline No & \multicolumn{2}{c}{ Interval Skor } & Kategori & Nilai \\
\hline 1 & $\mathrm{X} \geq \overline{\mathrm{X}}+1 . \mathrm{SB}_{\mathrm{x}}$ & $\mathrm{X} \geq 3,00$ & Sangat Baik & $\mathrm{A}$ \\
\hline 2 & $\overline{\mathrm{X}}+1 . \mathrm{SB}_{\mathrm{x}}>\mathrm{X} \geq \overline{\mathrm{X}}$ & $3,00>\mathrm{X} \geq 2,50$ & Baik & $\mathrm{B}$ \\
\hline 3 & $\overline{\mathrm{X}}>\mathrm{X} \geq \overline{\mathrm{X}}-1 . \mathrm{SB}_{\mathrm{x}}$ & $2,50>\mathrm{X} \geq 2,00$ & Cukup Baik & $\mathrm{C}$ \\
\hline 4 & $\mathrm{X}<\overline{\mathrm{X}}-1 . \mathrm{SB}_{\mathrm{x}}$ & $\mathrm{X}<2,00$ & Kurang Baik & $\mathrm{D}$ \\
\hline
\end{tabular}

Keterangan:

$$
\begin{aligned}
\overline{\mathrm{X}} & =\frac{1}{2}(\text { skor maksimal }+ \text { skor minimal }) \\
& =\frac{1}{2}(4,00+1,00) ; \quad=2,50 \\
\mathrm{SB}_{\mathrm{x}} & =\frac{1}{6}(\text { skor maksimal }- \text { skor minimal }) \\
& =\frac{1}{6}(4,00-1,00) ;=0,50
\end{aligned}
$$

Nilai kelayakan dan respon peserta didik dalam penelitian ini ditentukan dengan nilai minimal "C" yaitu kategori cukup baik. Dengan demikian, jika hasil penilaian oleh validator memberikan nilai akhir "C", maka produk sudah dianggap layak untuk digunakan.

\section{Hasil dan Pembahasan}

\section{Pendefinisian (Define) Media Pembelajaran Interaktif Berbasis Adobe Flash Professional CS6}

Tahap pendefinisian (Define) Media Pembelajaran Interaktif Berbasis Adobe Flash Professional CS6 terdiri dari analisis awal kebutuhan akan pengembangan media pembelajaran interaktif, analisis peserta didik untuk mengobservasi karakteristik mereka, analisis tugas-tugas utama yang akan dilakukan peserta didik terkait penerapan media pembelajaran, analisis konsep berupa peta pembelajaran, dan analisis tujuan pembelajaran terkait hal-hal yang ingin dicapai.

a. Analisis Awal

Analisis merupakan proses paling awal dan krusial yang wajib dilaksanakan sebelum memulai produksi. Analisis memaparkan pembelajaran yang memuat 
permasalahan dasar yang kemungkinan ditemui untuk meningkatkan tingkat profesionalitas pendidik dalam mata kuliah kemahiran menulis, dibutuhkan beragam analisis solusi yang terorganisasi dengan baik serta bersifat aplikatif, efektif, dan efisien. Solusi yang dirancang membutuhkan beragam pertimbangan untuk memudahkan pendidik mengetahui kelebihan dan kekurangan yang dimiliki serta mampu menyelesaikan permasalahan yang dihadapi. Dewasa ini, peserta didik memiliki banyak kebutuhan dalam pembelajaran, seperti kebutuhan memperoleh informasi, kebutuhan untuk dapat menguasai suatu keterampilan khusus (soft skill) sehingga mereka mampu bersaing dalam kompetisi dunia kerja, kebutuhan untuk memahami materi pembelajaran, serta kebutuhan lainnya yang tentu berbeda untuk masing-masing individu. Kaufman (1993) menjelaskan tentang pengertian kebutuhan (need) sebagai "Gap between the real condition and ideal condition" jarak atau kesenjangan antara kenyataan yang ada saat ini dengan keadaan yang sebenarnya terjadi tanpa adanya rekayasa.

Pendapat serupa dinyatakan Atwi Suparman (2000) yang mengatakan bahwa "Kebutuhan merupakan kesenjangan dari keadaan kini dengan keadaan sebenarnya yang terjadi yang sedang di alami oleh orang-orang." Suparman juga mengingatkan agar kebutuhan dan keinginan tidak dicampuradukkan. Kebutuhan yang menjadi sumber permasalahan harus diprioritaskan untuk segera dipecahkan dan mencari jalan alternatif yang bisa membantu dalam pemecahan masalah tersebut. Di sisi lain, keinginan berkaitan dengan pemecahan suatu masalah yang jika diperhatikan dengan seksama belum bersifat mendesak dan masih dapat ditunda pemenuhannya.

b. Analisis Karakteristik

Analisis karakteristik merupakan studi tentang peserta didik yang akan melakukan tahapan pembelajaran kemahiran menulis. Terdapat beberapa karakteristik peserta didik yang harus diidentifikasi sesuai desain dan pengembangan terkait media pembelajaran. Karakteristik yang penting untuk dianalisis adalah kompetensi yang sudah dimiliki peserta didik sebelum mengikuti pembelajaran kemahiran menulis. Analisis ini berkaitan dengan syarat-syarat kompetensi dan kondisi nyata peserta didik. Hal-hal yang diidentifikasi adalah sikap umum terhadap topik pembelajaran dan preferensi media, format, serta bahasa yang digunakan dalam pembelajaran kemahiran menulis.

c. Analisis Tugas

Proses analisis tugas dalam penerapan media Adobe Flash Professional CS6 pada mata kuliah kemahiran menulis adalah sebagai berikut:

1) Peserta didik ditugaskan menjelaskan sejarah aksara Bali dan mengenal aksara Bali tersebut dengan menulis review buku tentang sejarah aksara Bali secara berkelompok untuk dipresentasikan di kelas.

2) Peserta didik ditugaskan untuk menjelaskan aksara Bali dalam ranah pendidikan bahasa Bali dengan metode diskusi.

3) Peserta didik ditugaskan untuk mengenali evolusi bentuk aksara Bali dengan mendiskusikan dan mempresentasikan hasil pencariannya dari catatan sejarah awal keberadaan aksara di Bali. Tugas dapat dikerjakan dengan membuat powerpoint untuk mengenal bentuk aksara Bali dan berdiskusi dengan rekanrekan di kelompok.

4) Peserta didik ditugaskan untuk mempraktikkan penulisan ejaan-ejaan aksara Bali (ejaan Purwadresta sebelum tahun 1957, ejaan Purwadresta setelah tahun 1957, ejaan aksara Bali hasil Pasamuhan Agung tahun 1963, dan ejaan aksara Bali hasil Pasamuhan Agung tahun 1997). 
5) Peserta didik ditugaskan untuk mempresentasikan syarat-syarat penggunaan aksara Bali dalam ranah modern, mulai dari menulis singkatan, menulis nama, dan penulisan plang papan nama jalan atau usaha.

6) Peserta didik wajib mengikuti ujian tengah semester dan ujian akhir semester untuk mengukur keberhasilan pembelajaran.

d. Analisis Konsep

Peta konsep merupakan suatu rancangan yang berbentuk bagan terskema yang bertujuan untuk mendeskripsikan suatu pengertian yang terkonsep oleh seseorang dalam suatu rangkaian pernyataan. Selain untuk memaparkan aspek-aspek yang penting, setiap konsep yang ada saling dihubungkan oleh peta konsep sehingga mampu berkesinambungan. Menurut Buzan (2010: 5) peta konsep adalah cara yang baik untuk mendapatkan ide baru dan cara yang mudah untuk mendapatkan informasi dari otak.

Analisis konsep menjadi langkah penting dalam prinsip perancangan konsep materi yang dipilih sebagai sarana pencapaian kompetensi dasar dan standar kompetensi dalam pembelajaran kemahiran menulis terutama menulis aksara Bali. Capaian akhir pembelajaran peserta didik dalam mata kuliah kemahiran menulis membutuhkan metode, model, strategi, dan media yang sesuai yaitu adobe flash professional CS6. Penyampaian materi yang disajikan dengan media pembelajaran animasi berupa pembuatan video dapat didukung dengan diskusi dari peserta didik. Sebagaimana diketahui, media pembelajaran ini memiliki keunggulan di bidang tampilan. Diharapkan dengan animasi menarik serta para tokoh yang dapat berbincang-bincang secara interaktif dengan metode dubbing suara, peserta didik akan mendapatkan pengalaman belajar yang baru secara audio visual. Khusus dalam penerapan kali ini, titik fokus penggunaan media pembelajaran adalah untuk mata kuliah kemahiran menulis yang diajarkan di Program Studi Sastra Agama dan Pendidikan Bahasa Bali, Sekolah Tinggi Agama Hindu Negeri Mpu Kuturan Singaraja pada Semester III.

e. Analisis Tujuan Pembelajaran

Menurut Kompri (2016:219), belajar adalah komponen dari ilmu pendidikan yang berhubungan dengan tujuan dan bahan acuan interaksi, yang bersifat eksplisit maupun implisit. Analisis tujuan pembelajaran yaitu memilah tujuan pembelajaran yang merupakan konversi hasil analisis tugas dan analisis konsep menjadi tujuan yang dinyatakan dalam perilaku secara jelas dan terukur. Serangkaian tujuan ini menjadi dasar dalam pembuatan konstruksi pengujian (tes) dan desain instruksional. Tujuan ini diintegrasikan ke dalam bahan ajar (media pembelajaran) kemahiran menulis untuk digunakan oleh pendidik dan peserta didik sebagai panduan dalam mata kuliah kemahiran menulis dengan capaian agar peserta didik mengetahui lebih dalam mengenai aksara Bali terkait sejarah, penulisannya, pasang pageh aksara dan kompenen lain dalam kemahiran menulis aksara Bali.

f. Bentuk akhir

Media pembelajaran yang digunakan adalah penerapan aplikasi adobe flash professional CS6 ke dalam bentuk video pembelajaran yang disajikan secara audio visual. Video ini memiliki tiga orang tokoh yaitu Sang kakek bernama Pekak Regig dan kedua cucunya yaitu Mang Adi dan Luh Catri. Ketiga tokoh tersebut akan memandu peserta didik dalam video pembelajaran mata kuliah kemahiran menulis, mulai dari sejarah aksara Bali, fakta-fakta menarik di balik aksara Bali, tata cara penulisan aksara Bali, dan penggunaan aksara Bali dalam kehidupan bermasyarakat di Bali. 


\section{Tahap Perancangan (Design) Media Pembelajaran Interaktif Berbasis Adobe Flash Professional CS6}

Menurut Sommerville dalam buku Agus Mulyanto (2009 : 259) proses perancangan bisa melibatkan pengembangan beberapa model sistem pada tingkat abstraksi yang berbeda-beda. Menurut Soetam Rizky (2011 : 140) perancangan adalah sebuah proses untuk mendefinisikan sesuatu yang akan dikerjakan dengan menggunakan teknik yang bervariasi serta didalamnya melibatkan deskripsi mengenai arsitektur serta detail komponen dan juga keterbatasan yang akan dialami dalam proses pengerjaannya. Tahap perancangan ini bertujuan untuk merancang suatu media pembelajaran interaktif berbasis adobe flash professional CS6 yang dapat digunakan dalam pembelajaran pada Program Studi Sastra Agama dan Pendidikan Bahasa Bali dalam mata kuliah kemahiran menulis. Terdapat empat langkah yang wajib dilakukan pada tahap ini, terdiri dari penyusunan standar tes (criterion-test construction), pemilihan media (media selection), pemilihan format (format selection), membuat rancangan awal (initial design).

a. Penyusunan Tes atau criterion-test construction

Penyusunan Tes atau criterion-test construction merupakan kegiatan awal yang dilakukan untuk menemukan kemampuan awal peserta didik, dalam media pembelajaran berfungsi sebagai alat untuk evaluasi setelah dilaksanakan implementasi pembelajaran kemahiran menulis. Langkah-langkah penyusunan tes untuk dapat memperoleh alat penilaian (tes) yang memenuhi persyaratan, setiap penyusun tes hendaknya dapat mengikuti langkah-langkah penyusunan tes sebagai berikut:

1) Menyusun kisi-kisi (tabel spesifikasi) tes, yang memuat: materi pokok yang akan diteskan, aspek perilaku atau tingkatan kognitif yang akan diukur, dan penentuan jumlah butir tes untuk setiap aspeknya.

2) Menulis butir-butir soal dengan mendasarkan pada aspek-aspek yang telah tercantum pada tabel spesifikasi (kisi-kisi) tersebut.

3) Melakukan telaah soal tes (analisis tes secara logis);

4) Melakukan uji coba soal;

5) Analisis soal secara empiris;

6) Memperbaiki atau merevisi tes;

7) Merakit tes, dengan menyiapkan komponen-komponen pendukung untuk penyelenggaraan tes, yang meliputi: (a) buku tes; (b) lembar jawaban tes; (c) kunci jawaban tes; dan (d) pedoman penilaian atau pedoman pemberian skor.

8) Melaksanakan tes;

9) Menafsirkan hasil tes.

b. Pemilihan Media (Media Selection)

Menurut Winkel pemilihan media merupakan suatu hal yang konsisten dengan tujuan awalnya, selain harus konsisten ketika pemilihan media pendidik juga wajib menakar kemampuannya apakah mampu menguasai media tersebut atau tidak. Media yang di pilih menyesuaikan dengan analisis konsep dan analisis tugas. Hal tersebut berguna dalam membantu peserta didik mencapai kompentensi dasar. Sehingga pemilihan media dilakukan guna mengoptimalkan penggunaan bahan materi kuliah kemahiran menulis dalam proses pengembangan bahan ajar. Aplikasi Adobe Flash Professional CS6 terbilang efisien dalam menghasilkan media pembelajaran berbasis audio visual karena aplikasi Adobe Flash Professional CS6 menyediakan berbagai macam fitur yang sangat membantu para creator (pendidik) dalam membuat video animasi yang telah mampu mengolah teks maupun objek dengan efek tiga dimensi $(3 D)$ sehingga tampak lebih menarik. 


\section{c. Pemilihan format (format selection)}

Pemilihan format pada pengembangan perangkat pembelajaran di tujukan untuk mendesain isi dari pembelajaran, pemilihan strategi, pendekatan, metode pembelajaran, dan sumber belajar. Format yang digunakan yakni format flash (FLV atau F4V), karena format tersebut yang memenuhi kriteria efisiensi kapasitas serta memudahkan proses transfer data dalam membantu pembelajaran kemahiran menulis. Semua format ini dirangkum menjadi beberapa bagian dalam konteks kesatuan video pembelajaran pada aplikasi Adobe Flash Professional CS6

d. Rancangan awal (initial design)

Menurut Thiagarajan, dkk (1974: 7) "initial design is the presenting of the essential instruction through appropriate media and in a suitable sequence." Rancangan awal yang dimaksud adalah rancangan media pembelajaran yang harus dikerjakan sebelum ujicoba dilaksanakan. Rancangan ini berupa Draft I dari media pembelajaran interaktif berbasis Adobe Flash Professional CS6. Penelitian berbasis Adobe Flash Professional CS6 yang peneliti laksanakan dalam bentuk media pembelajaran berupa video animasi dengan materi mata kuliah kemahiran menulis, dikemas dengan rancangan dan langkah-langkah pelaksanaan di aplikasi Adobe Flash Professional CS6 adalah mengolah layer, menggambar dan menggolah objek, mengolah objek teks, mengolah animasi, mengolah simbol movie clip, mengolah simbol button, mengolah file sound, mengolah action script, mengimpor file video ke dalam flash professional cs6, mengolah publikasi animasi.

\section{Kelayakan dan Respon Pendidik serta Peserta Didik terhadap Media Pembelajaran Interaktif Berbasis Adobe Flash Professional Cs6}

Tahap ketiga dalam pengembangan media berdasarkan motode pengembangan 4D yaitu Develop (Pengembangan). Pada tahapan ketiga ini memiliki 2 tahapan yaitu validasi ahli, dan uji coba produk. Dari validasi ahli digunakan untuk mengetahui tingkat kelayakan media pembelajaran interaktif berbasis Adobe Flash Professional CS6, dan uji coba produk untuk mengetahui respon pendidik serta peserta didik terhadap media pembelajaran interaktif berbasis Adobe Flash Professional CS6 dengan langkah mengadakan uji coba terhadap peserta didik (mahasiswa) dan pendidik (dosen).

a. Kelayakan Media Pembelajaran Interaktif Berbasis Adobe Flash Professional CS6

Tahap develop (pengembangan) dilaksanakan setelah media pembelajaran selesai dibuat dengan cara melakukan validasi ahli perangkat dan validasi ahli materi.

1) Validasi Ahli Perangkat

Validasi yang dilaksanakan ahli perangakat dimanfaatkan untuk menguji tingkat kelayakan media pembelajaran interaktif berbasis Adobe Flash Professional CS6 yang dikembangkan oleh peneliti. Validasi yang dilaksanakan peneliti menguji dengan dua aspek, adapun aspek tersebut yaitu Aspek Perangkat Lunak dan Aspek Komunikasi Visual.

Tabel 4. Hasil dan Analisis dari Validasi Ahli Perangkat Pembelajaran

\begin{tabular}{llllll}
\hline No & \multicolumn{1}{c}{ Indikator Penilaian } & $\begin{array}{c}\text { Skor } \\
\text { (Ahli I) }\end{array}$ & $\begin{array}{c}\text { Skor } \\
\text { (Ahli II) }\end{array}$ & $\begin{array}{c}\text { Rata- } \\
\text { Rata Skor }\end{array}$ & Pesentase \\
\hline A & Aspek Perangkat Lunak & & & & \\
\hline 1 & Maintable & 3 & 3 & 3,00 & $75,00 \%$ \\
\hline 2 & Usable & 3 & 3 & 3,00 & $75,00 \%$ \\
\hline 3 & Compatible & 2 & 3 & 2,50 & $62,50 \%$ \\
\hline
\end{tabular}




\begin{tabular}{llllll}
\hline 4 & $\begin{array}{l}\text { Operasional multimedia } \\
\text { pembelajaran }\end{array}$ & 4 & 4 & 4,00 & $100 \%$ \\
\hline 5 & Reusable & 3 & 4 & 3,50 & $87,50 \%$ \\
\hline $\mathrm{B}$ & Aspek Komunikasi Visual & & & & \\
\hline 6 & Komunikatif & 4 & 4 & 4,00 & $100 \%$ \\
\hline 7 & Navigasi & 3 & 4 & 3,50 & $87,50 \%$ \\
\hline 8 & Audio & 4 & 4 & 4,00 & $100 \%$ \\
\hline $9 \quad$ Visual & 4 & 4 & 4,00 & $100 \%$ \\
\hline $10 \quad$ Animasi dan gambar & 4 & 4 & 4,00 & $100 \%$ \\
\hline Total Skor & 34 & 37 & 35,50 & $88,75 \%$ \\
\hline Rata-Rata Skor & 3,40 & 3,70 & 3,55 & $88,75 \%$ \\
\hline Persentase & $85,00 \%$ & $92,50 \%$ & $88,75 \%$ & - \\
\hline Kreteria & Layak & & \\
\hline
\end{tabular}

2) Validasi Ahli Materi

Validasi ahli materi digunakan untuk menilai materi yang ditampilkan pada media pembelajaran interaktif berbasis Adobe Flash Professional CS6. Materi ini mengacu pada Silabus dan Rencana Program Semester Mata Kuliah Kemahiran Menulis dengan kompetensi mengetahui dan menjelaskan sejarah Aksara Bali dan menjelaskan fungsi Aksara Bali Prodi Sastra Agama dan Pendidikan Bahasa Bali, STAHN Mpu Kuturan Singaraja.

Tabel 5. Hasil dan Analisis dari Validasi Ahli Materi

\begin{tabular}{llcccl}
\hline No & Kreteria Penilaian & $\begin{array}{c}\text { Skor } \\
\text { (Ahli I) }\end{array}$ & $\begin{array}{c}\text { Skor } \\
\text { (Ahli } \\
\text { II) }\end{array}$ & $\begin{array}{c}\text { Rata- } \\
\text { Rata } \\
\text { Skor }\end{array}$ & Persentase \\
\hline 1 & Kesesuain materi & 4 & 4 & 4,00 & $100 \%$ \\
\hline 2 & Kesesuaian konsep materi & 4 & 4 & 4,00 & $100 \%$ \\
\hline 3 & Kontekstualitas & 4 & 4 & 4,00 & $100 \%$ \\
\hline 4 & Kedalaman dan kelengkapan materi & 4 & 3 & 3,50 & $87,50 \%$ \\
\hline 5 & Kemudahan materi & 4 & 4 & 4,00 & $100 \%$ \\
\hline 6 & Sistematis, runtut, alur logis dan jelas & 4 & 4 & 4,00 & $100 \%$ \\
\hline 7 & Kejelasan uraian pembahasan & 3 & 4 & 3,50 & $87,50 \%$ \\
\hline 8 & Kesesuain jumlah latihan & 3 & 4 & 3,50 & $87,50 \%$ \\
\hline 9 & Materi pelajaran bisa di-review ulang & 3 & 3 & 3,00 & $75,00 \%$ \\
\hline 10 & Isi media memotivasi peserta didik & 4 & 4 & 4,00 & $100 \%$ \\
\hline Total Skor & 37 & 38 & 37,50 & $93,75 \%$ \\
\hline Rata-Rata Skor & 3,70 & 3,80 & 3,75 & $93,75 \%$ \\
\hline Pesentase & $92,50 \%$ & $95 \%$ & $93,75 \%$ & - \\
\hline Kreteria & \multicolumn{4}{l}{ Layak } \\
\hline
\end{tabular}

b. Respon Pendidik Terhadap Media Pembelajaran Interaktif Berbasis Adobe Flash Professional CS6

Respon pendidik terhadap media pembelajaran interaktif berbasis Adobe Flash Professional CS6 dilaksanakan dengan melaksanakan uji coba produk. mengukur respon pendidik (dosen) terhadap media pembelajaran interaktif berbasis Adobe Flash Professional CS6, peneliti menggunakan 12 kreteria yaitu 1) Ketersediaan dan kejelasan petunjuk, 2) Ketepatan judul media dengan materi, 3) Kesesuaian materi yang disajikan 
dalam media dengan kompetensi dasar, 4) Kesesuaian jenis huruf dalam media, 5) Bahasa yang digunakan dalam media, 6) Kemudahan navigasi dalam pengoperasian media, 7) Ketersediaan dan kejelasan petunjuk penggunaan media, 8) Kesesuaian latihan soal dalam media dengan materi yang disajikan, 9) Tampilan gambar dan animasi dalam media, 10) Motivasi belajar siswa setelah mengikuti pembelajaran dengan menggunakan media, 11) Cakupan materi yang terdapat dalam media, dan 12) Ketepatan pengembangan media Pembelajaran Interaktif Berbasis Adobe Flash Professional CS6 dengan materi konversi satuan waktu.

Grafik 1. Hasil dan Analisis Respon Pendidik

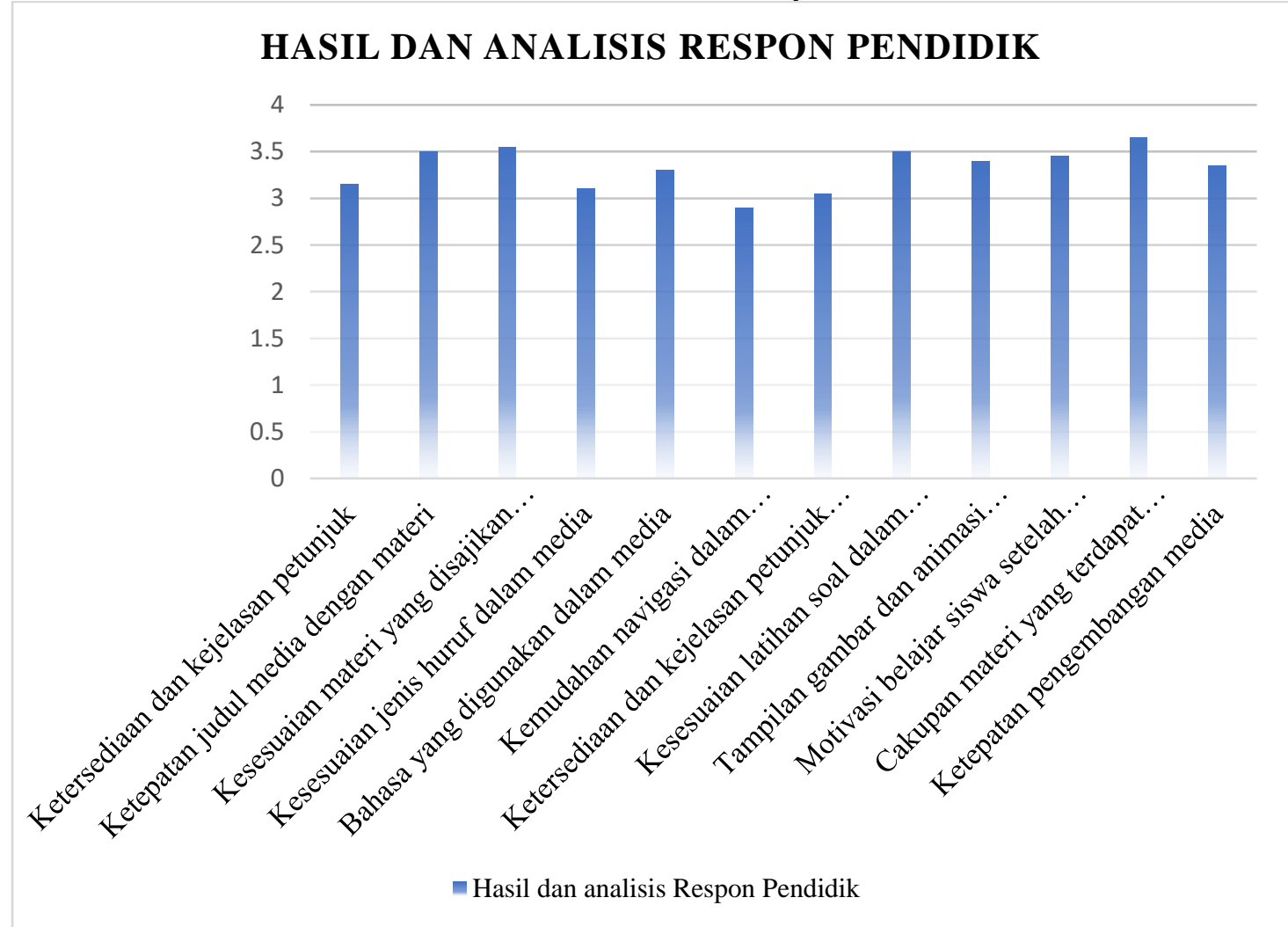

c. Respon Peserta Didik Terhadap Media Pembelajaran Interaktif Berbasis Adobe Flash Professional CS6

Respon peserta didik terhadap media pembelajaran interaktif berbasis Adobe Flash Professional CS6 dilaksanakan dengan cara yang sama seperti pendidik yaitu melaksanakan uji coba produk. Uji coba ini bertujuan untuk mencari data respon, reaksi atau komentar dari peserta didik Program Studi Sastra Agama dan Pendidikan Bahasa Bali. Sistem pengukuran respon pendidik (dosen) terhadap media pembelajaran interaktif berbasis Adobe Flash Professional CS6, peneliti menggunakan 11 kreteria yaitu 1) tampilan awal media, 2) kemudahan dalam memulai media, 3) kesesuaian jenis huruf dalam media, 4) tampilan gambar yang terdapat dalam media, 5) bahasa yang digunakan dalam media, 6) kemudahan navigasi dalam pengoperasian media, 7) ketersediaan dan kejelasan petunjuk penggunaan media, 8) pemahaman materi setelah menggunakan media, 9) kesesuaian latihan soal dalam media dengan materi yang disajikan, 10) kemandirian belajar dengan bantuan media, dan 11) kemenarikan dalam pembelajaran dengan menggunakan media. 
Grafik 2. Hasil dan analisis Respon Peserta Didik

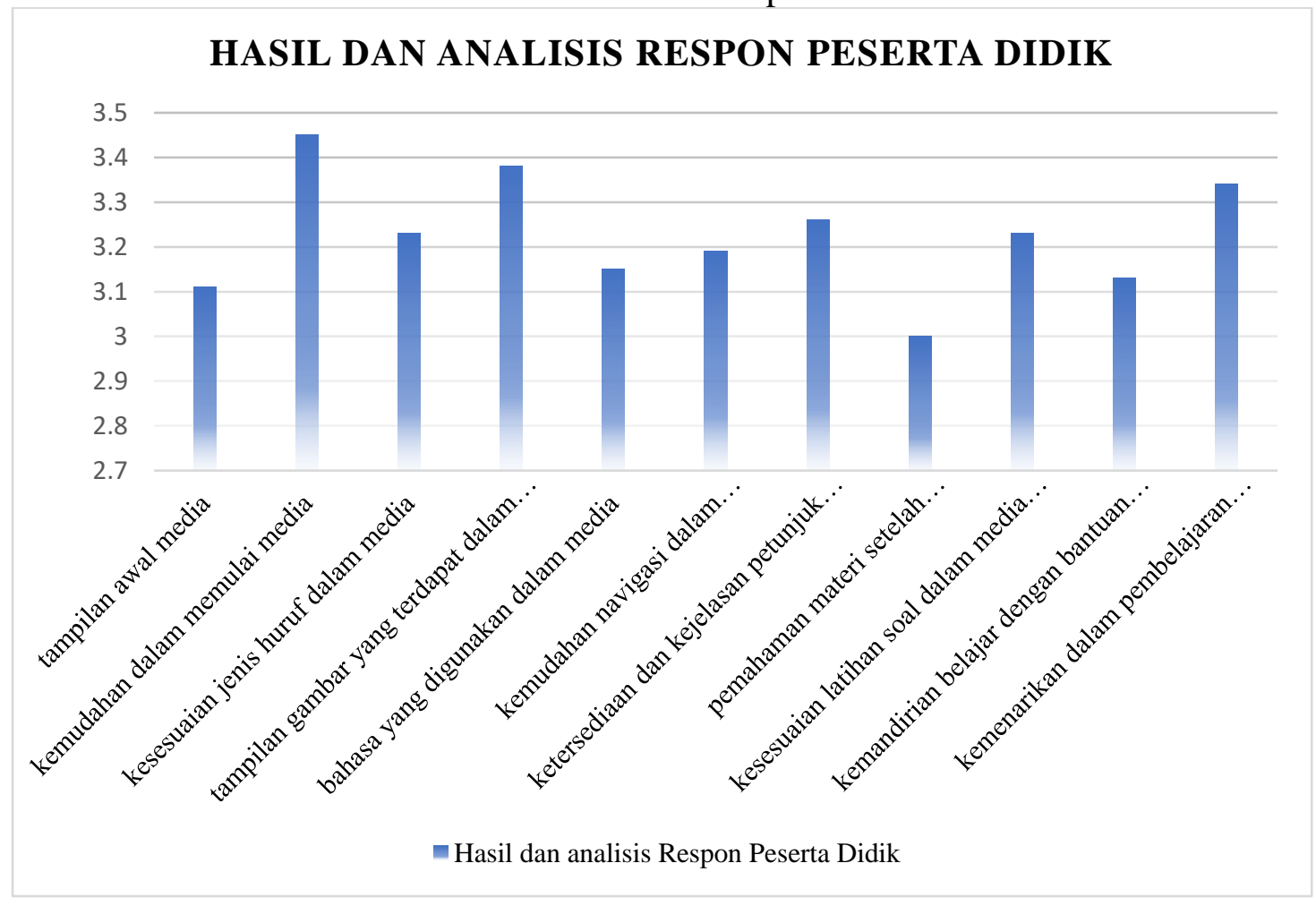

\section{Kesimpulan}

Pengembangan media media pembelajaran interaktif berbasis Adobe Flash Professional CS6 pada Program Studi Sastra Agama dan Pendidikan Bahasa Bali STAHN Mpu Kuturan Singaraja, dilaksanakan dengan beberapa tahapan dengan menggunakan model 4D, yang meliputi Define (Pendefinisian), Design (Perancangan), Develop (Pengembangan), dan Disseminate (Penyebaran). Berdasarkan hasil angket kebanyakan mahasiswa menginginkan adanya suatu inovasi dalam pembelajaran khususnya yang menggunakan audio visual beserta berisikan animasi. Tahap desain, peneliti menggunakan sebuah prototype yang digunakan pada saat tahap develop (pengembangan), sampai dengan uji coba produk kepada pendidik dan peserta didik.

Kelayakan produk media pembelajaran interaktif berbasis Adobe Flash Professional CS6 yang dikembangkan oleh peneliti ditentukan melalui beberapa tahap diantaranya validasi pengakat dan validasi ahli materi. Berdasarkan evaluasi yang dilaksanakan oleh ahli perangakat pembelajaran, media pembelajaran memiliki tingkat kelayakan dengan persentase sebesar $88,75 \%$. Sedangkan evaluasi yang dilaksanakan oleh ahli materi, media pembelajaran memiliki tiangkat kelayakan dengan persentase 93,75\%. Sehingga media pembelajaran interaktif berbasis Adobe Flash Professional CS6 layak digunakan.

Respon pendidik (dosen) dan peserta didik dengan hasil evaluasi uji coba kelompok pendidik media pembelajaran ini memperoleh respon dengan persentase $83,13 \%$ memuaskan. Sedangakn pada hasil evaluasi uji coba kelompok peserta didik media pembelajaran ini memperoleh respon dengan persentase $80,61 \%$ memuaskan. 


\section{Daftar Pustaka}

Aeni, A. N. (2014). Pendidikan Karakter Untuk Siswa SD Dalam Perspektif Islam. Universitas Pendidikan Indonesia: Mimbar Sekolah Dasar , 50.

Anwar, D. (2003). Kamus Besar Bahasa Indonesia. Indonesia/ Surabaya: Amelia.

Arikunto, S. Suhardjono. Supardi. (2006). Penelitian Tindakan Kelas. Jakarta: PT. Bumi Aksara.

Azwar, S. (2003). Metode Penelitian. Yogyakarta: Pustaka Pelajar.

Bungin, B. (2001). Metodologi Penelitian Sosial. Surabaya: Airlangga University Press.

Buzan, B. (2010). Culture and International Society. International Affairs Volume 86 , 5.

Cholid, Narboko. DKK. (2002). Metode Penelitian. Jakarta: Bumi Aksara.

Hasan, I. (2002). Pokok-pokok Metodologi Penelitian dan Aplikasinnya. Bandung: Ghalia Indonesia.

Heinich, R. et al. (1996). Instructional Media and Technologies For Learning. New Jersey: Prentice-Hall Inc.

Herayanti, Lovy. Fuaddunnazmi, M. Habibi. (2017). Pengembangan Media pembelajaran interaktif berbasis Moodle Pada Mata Kuliah Fisika Dasar . Cakrawala Pendidikan, 215-218.

Kompri. (2016). Motivasi Pembelajaran Perspektif Guru dan Siswa. Bandung: Rosda.

Lubis, Isma Ramadhani. Ikhsan, Jaslin. (2015). Pengembangan Media Pembelajaran Kimia Berbasis Android Untuk Meningkatkan Motivasi Belajar Dan Prestasi Kognitif Peserta Didik SMA. Jurnal Inovasi Pendidikan IPA, Volume 1, No. 2 , 5-7.

Madcoms. (2012). Adobe Flash Professional CS6 Untuk Pemula. Indonesia/ Yogyakarta: Andi, Madiun: Madcoms.

Madcoms. (2012). Kupas Tuntas Adobe Flash Professional CS6. Indonesia/ Yogyakarta: Penerbit Andi .

Mardapi, D. (2008). Teknik Penyusunan Instrumen Tes Dan Non Tes. Yogyakarta: Mitra Cendikia Press.

Mulyanto, A. (2009). Sistem Informasi Konsep dan Aplikasi. Yogyakarta: Pustaka Pelajar.

Novak, J. D., Gowin, D. B., Johansen, G. T. (1983). The Use of Concept Mapping and Knowledge Vee Mapping with Junior High School Science Students. Science Education , 1.

Richey, Rita C. Klein, James D. (2007). Design and Development Research Methods, Strategies and Issues. Routledge: Lawrence Erbaum Associates, Inc.

Sax, G. (1989). Principles of Educational and Psychological Measurement and Evaluation. Belmont California: Wads Worth Pub.

Seta, A. K. (1987). Konservasi Sumber Daya Tanah dan Air. Jakarta: Kalam Mulia.

Setyosari, P. (2010). Metode Penelitian Pendidikan dan Pengembangan. Jakarta: Kencana.

Sudaryono, D. (2019). Metodologi Penelitian Kuantitatif, Kualitatif, dan Mix Method. Depok: Rajawali Pers.

Sudikan, S. Y. (2001). Metode Penelitian Sastra Lisan. Surabaya: Citra Wacana.

Sugiyono. (2020). Metode Penelitian Kuantitatif, Kualitatif, dan R\&D. Bandung: Alfabeta.

Suissa, J. (2015). Character Education and the Disappearance of The Political. London: Institute of Education.

Supardi. (2006). Metodologi Penelitian. Mataram: Yayasan Cerdas Press.

Suparman, M. A. (1997). Model-model Pembelajaran Interaktif. Jakarta: STIA-LAN . 
Thiagarajan, S. Semmel, D.S. Semmel, M.I. . (1974). Instructional Development for Training Teacher of Exceptional Children. Bloomington Indiana: Indiana University.

Trianto. (2011). Model Pembelajaran Terpadu Konsep Strategi Dan Implementasinya Dalam Kurikulum Tingkat Satuan Pendidikan. Jakarta: Bumi Aksara.

V.S. Gerlach. D.P. Ely. (1971). Teaching and Media: A Systematic Approach . Boston: Prentice-Hall.

Wahyuningsih, A. N. (2011). Pengembangan Media Komik Bergambar Materi Sistem Saraf Untuk Pembelajaran Yang Menggunakan Strategi Pq4r. Universitas Negeri Semarang. Jurnal PP. Volume 1, No. 2 , 105-107.

Waryanto, N. H. (2006). Teknik Dasar Macromedia Flash. Yogyakarta: Laboratorium Komputer Jurusan Pendidikan Matematika Universitas Negeri Yogyakarta.

Wicaksono, S. R. (2011). Rekayasa Perangkat Lunak. Malang: Seribu Bintang. 